Journal of Southeast Asian

\title{
[Special Issue on SEA Demographics] Response - Sociology: A Portrait of Adaptation
}

Carl L. Bankston III

Tulane University, Carl.Bankston@tulane.edu

Follow this and additional works at: https://docs.lib.purdue.edu/jsaaea

Part of the Sociology Commons

\section{Recommended Citation}

Bankston, Carl L. III (2008) "[Special Issue on SEA Demographics] Response - Sociology: A Portrait of Adaptation," Journal of Southeast Asian American Education and Advancement: Vol. 3 : Iss. 1, Article 10. DOI: $10.7771 / 2153-8999.1106$

Available at: https://docs.lib.purdue.edu/jsaaea/vol3/iss1/10

This document has been made available through Purdue e-Pubs, a service of the Purdue University Libraries. Please contact epubs@purdue.edu for additional information.

This is an Open Access journal. This means that it uses a funding model that does not charge readers or their institutions for access. Readers may freely read, download, copy, distribute, print, search, or link to the full texts of articles. This journal is covered under the CC BY-NC-ND license. 


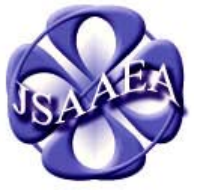

Volume 3
A peer-reviewed scholarly journal published by the National Association for the Education \& Advancement of Cambodian, Laotian, and Vietnamese Americans (NAFEA)

\title{
Special Issue on Southeast Asian American Demographics
}

\section{Response-Sociology: A Portrait of Adaptation}

\author{
Carl L. Bankston III \\ Tulane University
}

Dr. Pfeifer has provided a useful summary of the 2005 ACS data. His statistics are consistent with earlier descriptions of Southeast Asian populations using Census data, such as the description that Danielle Hidalgo and I recently published, relying mainly on full Census and the Public Use Micro Data Series (PUMS) from 1980 through 2000 (Bankston \& Hidalgo 2007a), and the description of the Vietnamese American population published by Rubén Rumbaut (2007). The use of Census data does raise the question of undercounting, a problem that Pfeifer himself acknowledges elsewhere, when he remarks that "it should be noted that it is widely believed that substantial undercounts occurred in the census enumerations of each of these predominantly immigrant and refugee populations” (Pfeifer, 2001). Based on interviews with Hmong community leaders, I have identified census undercounting as apparently a serious problem for this group, in particular (Bankston, 1995, 2000). Drastic undercounting, especially of children, may be the reason that the ACS and 2000 Census data for the Hmong show a very small increase in population, in both rate and numbers, from 2000 to 2005, while the Hmong tend to have very large families (see Table 12), which should reflect high fertility and a consequent high rate of population growth.

The definition of group membership may also create some ambiguities. The “... alone or in any combination" definition includes individuals of mixed ethnicity. In the 2000 Census, for example, there was a difference of over 100,000 people between "Vietnamese alone or in any combination" and "Vietnamese alone," or over 8\% of the entire population. Among those under 18 years of age, $13 \%$ of the "Vietnamese alone or in any combination" category were "any combination," rather than "Vietnamese alone." Thus, the definition that Pfeifer uses includes some fairly large numbers and proportions of people whose own ethnicity may be complicated, whose parents and other family are not members of the groups under consideration, and who may be quite distinct from other group members, especially in characteristics related to cultural and socioeconomic assimilation. The offspring of Southeast Asian partners or spouses of nonAsian American military personnel formerly stationed in Southeast Asia make up one particularly distinctive sub-group whose demographic characteristics may be quite different from other Southeast Asians and whose ethnic self-identification may be complicated (Hidalgo \& Bankston, forthcoming). The fact that younger and, therefore native-born, people are more likely to be mixed race can introduce some systematic, if small, bias into many of the descriptive measures.

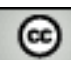

SORERIGHISRESERVEDReaders are free to copy, display, and distribute this article, as long as the work is attributed to the author(s) and the Journal of Southeast Asian American Education \& Advancement, it is distributed for noncommercial purposes only, and no alteration or transformation is made in the work. More details of this Creative Commons license are available at http://creativecommons.org/licenses/by-nc-nd/3.0/. All other uses must be approved by the author(s) or JSAAEA. 
Keeping these concerns in mind, this descriptive summary is significant for social scientists concerned with Southeast Asian origin populations in the United States. Several showed substantial recorded population increases from 2000 to 2005: The Vietnamese population showed an increase of $24 \%$, the Cambodian an increase of $17 \%$, the Lao $6 \%$, and the Hmong population an increase of $1.4 \%$. As Pfeifer notes, this last increase may not include the 15,000 Hmong who came from 2004 to 2006 and, as I note above, even excluding those new arrivals, real Hmong population growth may have been much greater. This would indicate that these statistics give us a very conservative measure of the rapid increase of Southeast Asians in the United States.

One of the implications of this growth is that several Southeast Asian groups will make up a much larger proportion of the American population in the foreseeable future. To put the above growth in context, the American population as a whole grew by $2.5 \%$ between 2000 and 2005, a lower rate of growth than any of the Southeast Asian groups except the Hmong (and even the Hmong may have grown by more if the 2004 through 2006 arrivals were left out). The rate of growth of the Vietnamese American population was especially great, and the Vietnamese were already one of the largest Asian American groups by 2000. In terms of sheer numbers, Southeast Asians are an important segment of the people of the United States and the segment is growing steadily.

Another observation that should be made about this population growth is that it is happening after the era of large-scale Southeast Asian refugee movements that established all of these groups in North America from 1975 until the early 1990s. The 2004 to 2006 entry of Hmong mentioned by Pfeifer was something of an anomaly. As reflected in Pfeifer's section on time of arrival, the flow of refugees originating from Vietnam, Cambodia, and Laos peaked in the 1980s and for the most part ended by the early 1990s (Bankston \& Hidalgo, 2007a, 2007b; Zhou \& Bankston, 1998). While there was some non-refugee migration after this period, most of the growth occurred by births inside of the United States. This is reflected in Pfeifer's Table 18. Although the majority of all groups except the Hmong were foreign born, they all had substantial native born populations and the fact that nearly $36 \%$ of the Vietnamese American population was American born is impressive when one considers that the entire group has been established through migration over the past thirty years.

As the native born portion of these groups grows, it is probable that family sizes will become more similar to those of the general population, shown in Table 12 and that growth in population through native fertility will slow down. However, there are reasons to believe that immigration, especially from Vietnam, will grow. Already, immigrant admissions from mainland Southeast Asia have increased while refugee admissions have dropped (Bankston \& Hidalgo, 2007a, 2007b). A large population of any national group in the United States increases opportunities for migration from the ancestral homeland because family reunification is the primary preference category in American immigration policy. Accordingly, Pfeifer aptly observes that much Vietnamese migration after the 1990s was probably the result of family reunification migration. In general, one can expect both a slowing of population growth through native birth, and an increase in population growth through migration, unless there is a change in American immigration law. Both of these trends mark what may be called the "normalization" of the Southeast Asian groups that originated as refugees. The native-born groups are becoming more similar, in basic demographic characteristics, to members of other American ethnic groups, and the new immigrants are becoming more like other new immigrants to the United States in their means of arrival. 
The socioeconomic and educational progress of these groups marks their rapid adaptation to American society. Adaptation, though, is not the same thing as assimilation. In fact, the progress of some groups actually distinguishes them from much of American society. Vietnamese American youth, in particular, have long been noted for their school performance (Zhou \& Bankston, 1998). Whether their differences from the Laotians and Cambodians in this respect can be entirely attributed to the relatively higher level of availability of education in Vietnam, as Pfeifer suggests, is open to question. Min Zhou and I (1998) found that even Vietnamese children from extremely limited educational backgrounds are often comparatively high achievers. We have located the sources of academic achievement in the frequently close ethnic community networks that surround Vietnamese American children. It may be reasonable to suggest, then, that at least part of the difference among these groups may lie in structures of their ethnic networks. It may also be the case, as my co-authors and I have argued about Cambodians, that the tragic experiences of their homeland have placed increased stress on them, slowing upward mobility (Bankston \& Hidalgo, 2007b; Zhou, Bankston, \& Kim, 2001).

If the educational progress of the Southeast Asian groups is a product of ethnic social relations, then this distinctiveness may diminish as young people take on characteristics of the other young people who surround them in this country. Already, in revisiting the Vietnamese community that we studied in the 1990s, Min Zhou and I have found that the high achieving Vietnamese adolescent, while still part of the scene, is becoming somewhat less common (Zhou \& Bankston, 2006).

The general economic progress noted by Pfeifer is impressive. When we see that the Vietnamese and Lao have higher median household and family incomes than the American population as a whole, though, it is important to remember that all of these groups were disproportionately located in California, where both wages and the cost of living tend to be higher than many other parts of the country. In addition, as Pfeifer points out, there is substantial variability within these groups as well as among them. As Table 22 shows, all groups had higher poverty rates than the American population in general, with the Hmong especially disadvantaged, since about one third live below the poverty level.

Overall, Mark Pfeifer has done an excellent job of summarizing and describing for us the most important Census statistics on the adaptation of Southeast Asians to life in the United States. This is a picture that shows remarkable achievements over a short period of history, as well as remaining challenges.

\section{References}

Bankston, C. L. III. (1995). Who are the Hmong Americans? In I. Natividad (Ed.), Asian American Almanac (pp. 81-89). Detroit: Gale Research, Inc.

Bankston, C. L. III. (2000). Hmong Americans. In R. V. Dassanowsky \& J. Lehman (Eds.), Gale encyclopedia of multicultural America ( ${ }^{\text {nd }}$ ed., pp. 322-327). Detroit: Thomson Gale.

Bankston, C. L. III \& Hidalgo, D. A. (2007a). Southeast Asia: Laos, Cambodia, Thailand. In M. C. Waters \& R. Ueda with H. B. Marrow (Eds.), The new Americans: A guide to immigration since 1965 (pp. 624-640).Cambridge: Harvard University Press.

Bankston, C. L. III \& Hidalgo, D. A. (2007b). The waves of war: Immigrants, refugees, and new Americans from Southeast Asia. In M. Zhou \& J. V. Gatewood (Eds.), Contemporary Asian America ( $2^{\text {nd }}$ ed., pp. 260-292). Albany: New York University Press. 
Hidalgo, D. A. \& Bankston, C. L. III. (Forthcoming). War brides and refugees: Shifting links to the military, 1980-2000. International migration.

Pfeifer, M. (2001). 2000 Census shows contrasting growth and settlement patterns of 4 major Southeast Asian origin groups. Retrieved June 2, 2008 from http://hmongstudies.com/4IndochineseGroups.html

Rumbaut, R. (2007). Vietnam. In M. C. Waters \& R. Ueda with H. B. Marrow (Eds.), The new Americans: A guide to immigration since 1965 (pp. 652-673). Cambridge: Harvard University Press.

Zhou, M. \& Bankston, C. L. III. (1998). Growing up American: How Vietnamese children adapt to life in the United States. New York: Russell Sage Foundation.

Zhou, M. \& Bankston, C. L. III. (2006). Delinquency and acculturation in the Twenty First Century: A decade's change in a Vietnamese American community. In R. Martinez, Jr. \& A. Valenzuela, Jr. (Eds.), Immigration and crime: Ethnicity, race, and violence (pp. 154190). New York University Press.

Zhou, M.; Bankston, C.L. III \& Rebecca Kim, R. (2001). Rebuilding spiritual lives in the new land: Religious practices among Southeast Asian refugees in the United States. In P. Gap Min and J. Ha Kim (Eds.), Asian immigration and transplanting and transforming religions (pp. 37-70). Walnut Creek: Altamir.

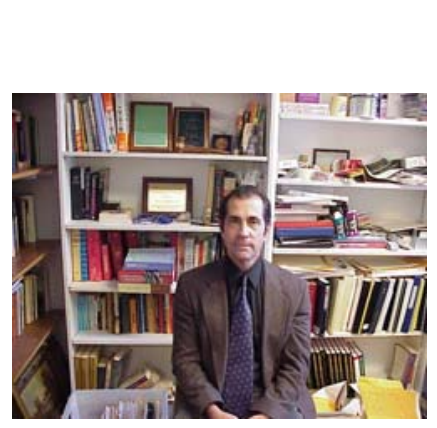

About the Author

Carl L. Bankston III is Chair of the Department of Sociology and Director of the Asian Studies Program at Tulane University. His research interests focus on Asian migration and sociology of education. He has published over one hundred articles and book chapters and fifteen books, including Growing Up American: How Vietnamese Children Adapt to Life in the United States (1998), coauthored with Min Zhou. 


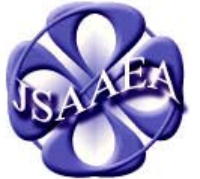

Volume 3

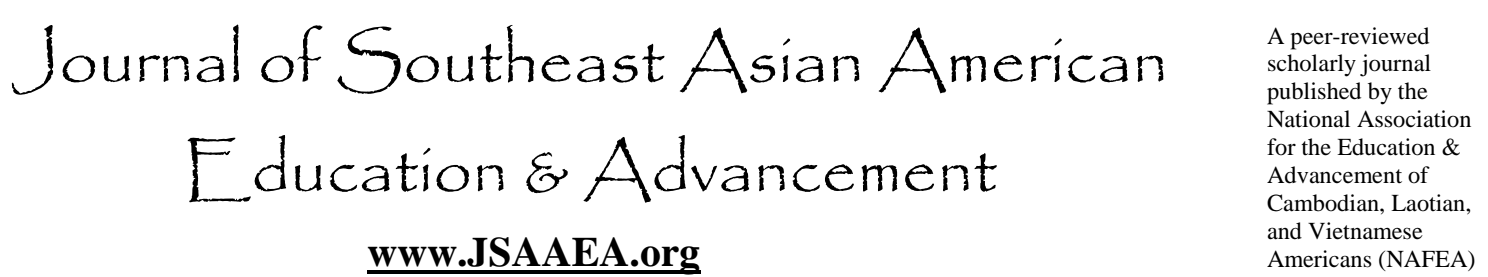

Editor

Dr. Wayne E. Wright

University of Texas, San Antonio

Associate Editors

Dr. Chhany Sak-Humphry

University of Hawaii

Dr. KimOanh Nguyen-Lam

California State University, Long Beach

Book Review Editor

Dr. Leslie Turpin

School for International Training

Creative Works Editor

Phouang Hamilton

Washington Office of Superintendent of Public Instruction

Special Advisor

Anne Frank

University of California, Irvine, Southeast Asian Archives

Editorial Assistant

Mariana Kuhl

University of Texas, San Antonio

Comments and questions for the editorial staff may be directed to jsaaea@lists.sis.utsa.edu

\section{Editorial Review Board}

\author{
Dr. Carl L. Bankston III \\ Tulane University \\ Dr. Phala Chea \\ Lowell Public Schools \\ Dr. Changming Duan \\ University of Missouri, Kansas City \\ Dr. Nancy H. Hornberger \\ University of Pennsylvania \\ Dr. Peter Nien-Chu Kiang \\ University of Massachusetts, Boston \\ Dr. Stacey Lee \\ University of Wisconsin, Madison
}

\author{
Dr. Pollie Bith-Melander \\ Asian and Pacific Islander Wellness Center \\ Dr. George Chigas \\ University of Massachusetts, Lowell \\ Dr. Sophal Ear \\ U.S. Naval Postgraduate School \\ Dr. Samlong Inthaly \\ Minneapolis Public Schools \\ Dr. Kevin K. Kumashiro \\ University of Illinois, Chicago \\ Dr. David Chanpannha Ley \\ Montgomery County Public Schools
}


Dr. Sue Needham

California State University, Dominguez Hills

Dr. Max Niedzwiecki

Rights Working Group

Dr. Clara Park

California State University, Northridge

Dr. Loan T. Phan

University of New Hampshire

Dr. Karen Quintiliani

California State University, Long Beach

Dr. Fay Shin

California State University, Long Beach

Dr. Yer J. Thao

Portland State University

Dr. Khatharya Um

University of California, Berkeley

Dr. Terrence G. Wiley

Arizona State University

\section{Dr. Bic Ngo}

University of Wisconsin-Madison

Dr. Leakhena Nou

California State University, Long Beach

Dr. Mark Pfeifer

Texas A\&M University, Corpus Christi

Dr. Bounlieng Phommasouvanh

Minnesota Department of Education

Dr. Kalyani Rai

University of Wisconsin, Milwaukee

Dr. Nancy J. Smith-Hefner

Boston University

Dr. Myluong Tran

San Diego State University

Dr. Linda Trinh Vo

University of California, Irvine

Dr. Zha Blong Xiong

University of Minnesota

Dr. Kou Yang

California State University, Stanislaus

\section{Doctoral Student Editorial Review Board}

\author{
Keo Chea \\ University of Pennsylvania \\ Loan Dao \\ University of California, Berkeley \\ Ha Lam \\ Arizona State University \\ Vanna Som \\ Harvard University \\ Giang Pham \\ University of Minnesota \\ Tinou Tran \\ University of Houston, Texas \\ Phitsamay Sychitkokhong Uy \\ Harvard University
}

Vichet Chhuon

University of California, Santa Barbara

Annie BichLoan Duong

San Joaquin County Office of Education

Ravy Lao

University of California, Santa Barbara

Rassamichanh Souryasack

University of California, Santa Barbara

Layheng Ting

State University of New York, Albany

Loan Tran

University of California, Santa Barbara

Yang Sao Xiong

University of California, Los Angeles 